\title{
BIOGENESIS OF MITOCHONDRIA
}

\author{
XI. A Comparison of the Effects of \\ Growth-Limiting Oxygen Tension, \\ Intercalating Agents, and Antibiotics \\ on the Obligate Aerobe Candida Parapsilosis
}

\author{
G. M. KELLERMAN, D. R. BIGGS, and ANTHONY W. LINNANE \\ From the Biochemistry Department, Monash University, Clayton, Victoria 3168, Australia
}

\begin{abstract}
Growth under conditions of oxygen restriction results in a generalized decrease in the definition of the mitochondrial membranes, a decrease in the mitochondrial cytochromes, and a decrease in citric acid cycle enzymes of the obligate aerobic yeast Candida parapsilosis. Addition of unsaturated fatty acids and ergosterol to cultures exposed to limited oxygen results in improved definition of the mitochondrial membranes and an increase in the total mitochondrial cytochrome content of the cells. Euflavine completely inhibits mitochondrial protein synthesis in vitro. Its in vivo effect is to cause the formation of giant mitochondrial profiles with apparently intact outer membranes and modified internal membranes; the cristae (in-folds) appear only as apparently disorganized remnants while the remainder of the inner membrane seems intact. Cytochromes $a, a_{3}, b$, and $c_{1}$ are not synthesized by the cells in the presence of euflavine. Ethidium appears to have effects identical to those of euflavine, whereas chloramphenicol, lincomycin, and erythromycin have similar effects in principle but they are less marked. The effects of all the inhibitors are freely reversible after removal of the drugs. The results are discussed in terms of a functionally three-membrane model of the mitochondrion. In addition, the phylogenetic implications of the observed differences between this organism and the facultative anaerobic yeasts are considered.
\end{abstract}

\section{INTRODUCTION}

The formation of mitochondria in the facultative anaerobic yeast, Saccharomyces cerevisiae, can be influenced by a number of factors. In the first place, anaerobic growth does not occur without the addition to the growth medium of the essential lipids, ergosterol and unsaturated fatty acid, the biosynthesis of which requires molecular oxygen. After anaerobic growth in the presence of adequate amounts of these lipids, extensive structural changes are found in the mitochondria and the mitochondrial cytochromes $a, a_{3}, b, c_{1}$, and $c$ are no longer synthesized. However, after anaerobic growth with limiting lipid mitochondrial profiles often are not even recognizable (Linnane, 1965; Wallace et al., 1968). Following aeration of any type of anaerobically grown cell, mitochondria of normal architecture and cytochrome content are found. In the second place, cells grown aerobically in the presence of certain antibiotics, such as chloramphenicol, erythromycin, 
or lincomycin suffer a progressive loss of the cytochromes $a, a_{3}, b$, and $c_{1}$ and there are associated morphological changes in the mitochondria; these effects are reversible upon removal of the antibiotics (Clark-Walker and Linnane, 1966, 1967; Linnane, Biggs et al., 1968). Finally, cells grown in the presence of certain acridines such as euflavine also lose their cytochromes $a, a_{i}$, $b$, and $c_{1}$, but whereas the antibiotic effect is reversible, treatment with euflavine causes a genetic change resulting in the formation of the so-called cytoplasmic "petite" mutant (Ephrussi, 1953).

Extension of such studies to phylogenetically more advanced cells, such as mammalian cells, has been limited by the difficulty of their manipulation, therefore there has been a tendency to generalize widely from the information obtained with yeast (for review Linnane, 1968 and footnote 1). However, recent limited studies on mammalian cells and mitochondria have shown some differences in certain aspects from the yeast results. Thus, mammalian mitochondrial protein synthesis is inhibited by chloramphenicol both in vivo and in vitro, as occurs in yeast, but on the other hand, mammalian mitochondrial protein synthesis is unaffected by lincomycin or erythromycin (Firkin and Linnane, 1968, and footnotes 2 and 3). It is perhaps relevant that the molecular organization of mitochondrial DNA has been found to be super-helical in multicellular organisms, whereas in $S$. cerevisiae mitochondrial DNA may or may not be circular. If present, circularity is achieved by virtue of terminal base complementarity and not covalent bond formation (Shapiro et al., 1968).

It is the purpose of the present communication to report a comparative study of the effects of oxygen restriction, antibiotics, and euflavine on several parameters of mitochondrial behaviour in Candida parapsilosis, a yeast which is an obligate aerobe and therefore more closely resembles the mammalian cell. ${ }^{4}$ This organism does respond to

${ }^{1}$ P. Borst and A. M. Kroon. 1968. International Review of Cytology. In press.

${ }^{2}$ F. C. Firkin and A. W. Linnane. 1969. Exp. Cell Res. In press.

${ }^{3}$ F. C. Firkin and A. W. Linnane. 1969. FEBS Letters. In press.

${ }^{4}$ Papers 9 and 10 in this series appear respectively in Archives of Biochemistry and Biophysics, 1969, 130:235 and Genetics, 1969, in press. restriction of oxygen supply and euflavine quite differently from Saccharomyces. In addition, its response to chloramphenicol suggests that some modification is necessary on the simple model proposed for mitochondrial biogenesis of an outer membrane synthesized by the cytoplasmic ribosomes, and cristae synthesized in part both by cytoplasmic ribosomes and by the mitochondrial protein-synthesizing system. The present results raise the possibility that mitochondria consist functionally of a three-membrane system, viz. an outer membrane enclosing a two-component inner membrane, the latter made up of the cristae (in-folds) which normally are continuous with the rest of the noncristal inner membrane. The insoluble cytochromes $a, a_{3}, b$, and $c_{1}$ may be located only in the cristae.

Preliminary reports on the effect of oxygen and chloramphenicol on the organism have previously been published (Biggs and Linnane, 1963; Linnane, Biggs et al., 1968).

\section{MATERIALS AND METHODS}

\section{Organism}

The locally isolated aerobic yeast used throughout the experiments was identified as Candida parapsilosis (Lodder and Kreger-Van Rij, 1967).

\section{Growth Media}

The liquid medium used for cultivation of the cells contained $0.5 \%$ Difco yeast extract, $0.12 \%$ $\left(\mathrm{NH}_{4}\right)_{2} \mathrm{SO}_{4}, 0.05 \% \mathrm{NaCl}, 0.07 \% \mathrm{MgCl}_{2} \cdot 6 \mathrm{H}_{2} \mathrm{O}$, $0.1 \% \mathrm{KH}_{2} \mathrm{PO}_{4}, 0.01 \% \mathrm{CaCl}_{2}, 0.0005 \% \mathrm{FeCl}_{3}$, and $5 \%$ glucose. Other additions to this basic medium are detailed in the text.

\section{Growth Conditions}

Cultures were grown in 15 liters of medium in an 18 liter carboy fitted with a sintered glass aerator through which a metered air flow could be maintained. The rates of air flow per 30 liters of medium were standardized at 20-24 liters/min (high aeration), $250-300 \mathrm{ml} / \mathrm{min}$ (medium aeration) or $40-50 \mathrm{ml} /$ min (low aeration). For medium and low aeration cultures the medium was vigorously stirred with a motor-driven double-bladed paddle at $250 \mathrm{rpm}$. Oxygen tension of the medium was measured polarographically. The effects of the antibiotics and other drugs were studied only under conditions of high aeration.

\section{Respiration}

Whole cell respiration was determined polarographically or in Warburg manometers. Cyanide 
sensitivity of cell respiration at an equilibrium concentration of $0.5 \mathrm{~mm}$ was determined as described by Robbie (1948).

\section{Enzyme Assays}

Cells were completely disrupted by two passages through a French pressure cell at $\mathbf{8}$ tons per square inch (Clark-Walker and Linnane, 1967). Large fragments of cell debris were removed by two centrifugations each at $1,000 \mathrm{~g}$ for $10 \mathrm{~min}$ to yield a cell-free "whole homogenate". A "total particle fraction" was prepared by centrifugation of the whole homogenate at $75,000 \mathrm{~g}$ for $90 \mathrm{~min}$. Determinations of cytochrome content of whole cells or particles, other enzyme determinations, and electron microscopy were performed as described by Clark-Walker and Linnane (1967). Cytochrome $c$ content of whole cells was determined as described by Sels et al. (1965).

\section{Amino Acid Incorporation}

Mitochondria were prepared by subjecting to osmotic shock the protoplasts prepared by treating high aeration cells with snail gut enzymes, as described by Lamb et al. (1968). The measurement of the incorporation of ${ }^{14} \mathrm{C}$-leucine into mitochondrial protein was also as described by these authors.

\section{RESULTS}

\section{Cell Growth Rate and Yields}

The effect of the three aeration regimes on the growth of the organism is shown in Fig. 1 a. Under conditions of high aeration in the large carboys the organism had a generation time of 1.4 hr and a final yield of about $4 \times 10^{8}$ cells $/ \mathrm{ml}$, corresponding to $5 \mathrm{mg}$ dry weight cells per $\mathrm{ml}$ of medium. At the intermediate and low aeration rates the generation time was increased to about 2.5 to $2.6 \mathrm{hr}$ in each case but the final yield was reduced to about $6 \times 10^{7}$ and $3 \times 10^{7}$ cells $/ \mathrm{ml}$, respectively; or in other words, to 16 and $8 \%$ of the yield obtained under the high aeration conditions. Under conditions of strict anaerobiosis there was no significant growth of the organism on the normal medium. It is possible to achieve markedly enhanced growth of facultative anaerobic yeasts such as those of the Saccharomyces genus by the inclusion of excess unsaturated fatty acid (0.5\% Tween 80$)$ and ergosterol $(0.002 \%)$ in the lipid-poor normal medium; these lipid components are essential for the growth of the organism and require molecular oxygen for their biosynthesis (Jollow et al., 1968). However, addition of these lipids in excess did not permit

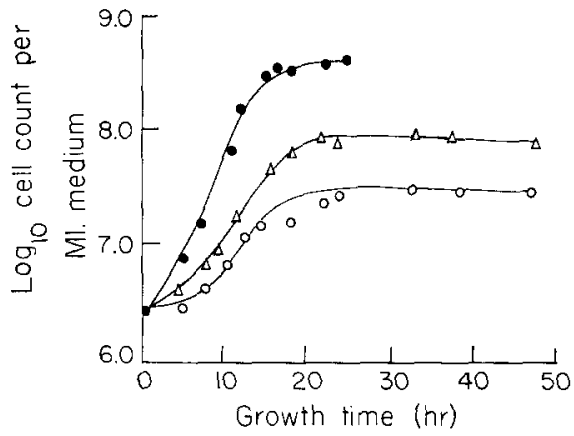

(a)

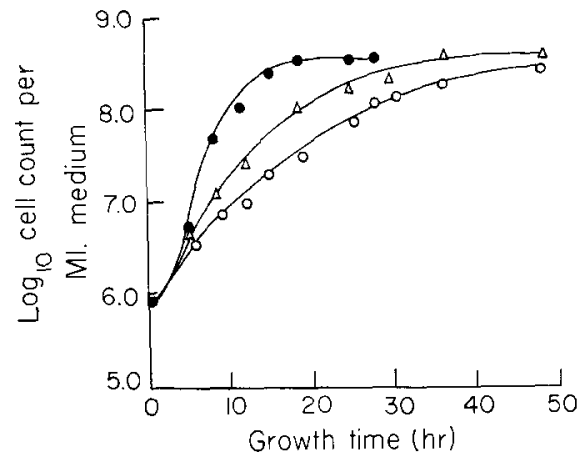

(b)

Figure 1 The effect of oxygen lack, chloramphenicol and euflavine on the growth characteristics of C. parapsilosis. (a) - - High aeration cells; $\triangle-\triangle$, Cells grown in media aerated at $250-300 \mathrm{ml}$ air/30 1 medium/minute; $\mathrm{O}-\mathrm{O}$, Cells grown in media aerated at $40-60 \mathrm{ml}$ air $/ 301 \mathrm{medium} /$ minute. (b) - - Control cells grown on the basic medium; $\triangle-\triangle$, Cells grown on the basic medium containing $4 \mathrm{mg} / \mathrm{ml}$ of chloramphenicol or $5 \mu \mathrm{g} / \mathrm{ml}$ euflavine; O- 0 , Cells grown on the basic medium containing $20 \mu \mathrm{g} / \mathrm{ml}$ of euflavine.

growth of Candida parapsilosis in the complete absence of oxygen and led to only minor increases in growth under conditions of low aeration. Hence, a deficiency of these lipid components is not responsible for the limited growth of the cells under low aeration.

Fig. $1 \mathrm{~b}$ depicts the effect of chloramphenicol and euflavine on cell growth. In contrast to restriction of oxygen supply, which affected both growth rate and final cell yield, chloramphenicol at concentrations as high as $4 \mathrm{mg} / \mathrm{ml}$ of medium, which is close to the limit of solubility, resulted only in prolongation of the generation time in the logarithmic phase from the normal $1.4 \mathrm{hr}$ 


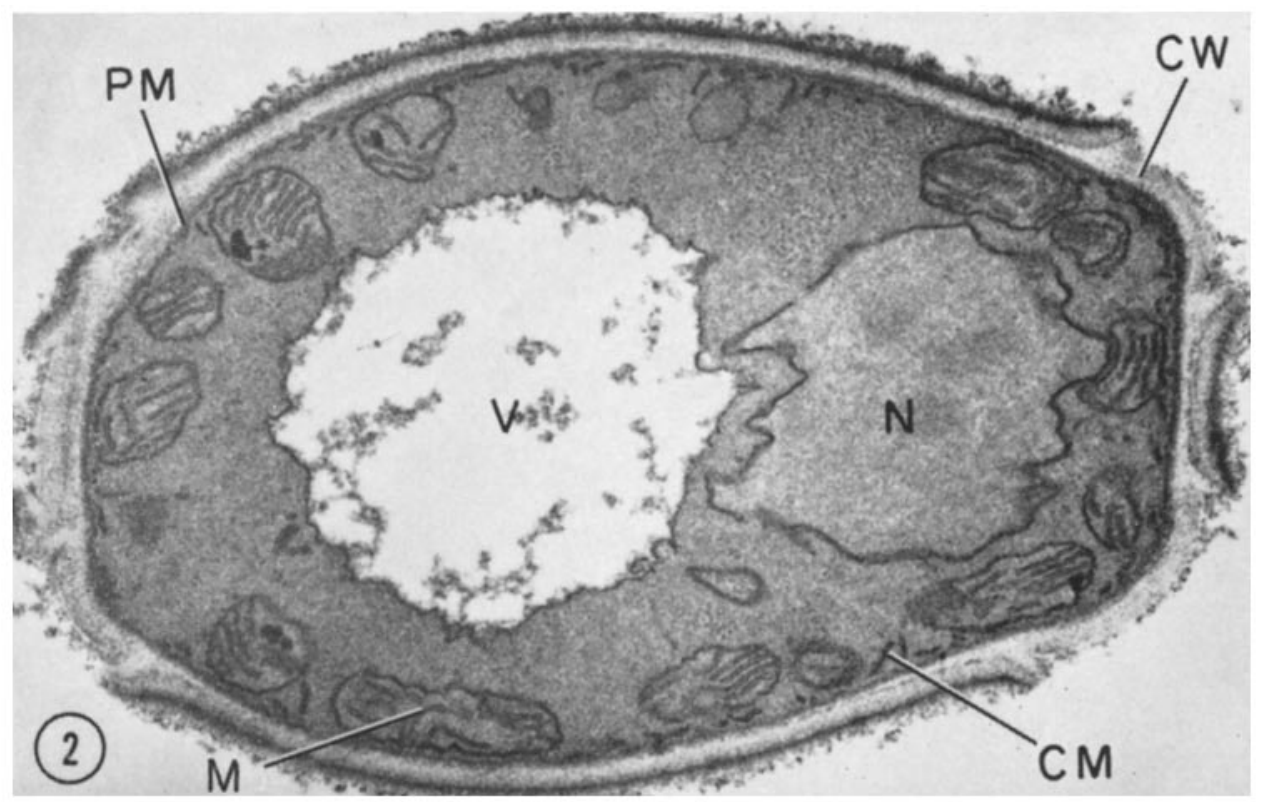

Figure 2 Section through a cell of $C$. parapsilosis grown under high aeration conditions in the basic medium, showing a prominent cell wall $(C W)$, plasma membrane $(P M)$, nucleus $(N)$, and vacuole $(V)$. The mitochondria $(M)$ are large and well-defined and characteristically contain numerous cristae. Only small amounts of free cytoplasmic membrane $(C M)$ are observed in these cells. $\times 29,000$.

to $2.8 \mathrm{hr}$, but the final cell yield was unaltered. Euflavine at $5 \mu \mathrm{g} / \mathrm{ml}$ gave a growth curve similar to that of chloramphenicol at $4 \mathrm{mg} / \mathrm{ml}$, but growth in the presence of euflavine at a concentration of $20 \mu \mathrm{g} / \mathrm{ml}$ increased the generation time to $4.3 \mathrm{hr}$ and decreased the final cell yield by about $30 \%$.

\section{Morphological Effects}

Fig. 2 shows an electron micrograph of a normal C. parapsilosis cell grown under the high aeration conditions, showing the presence of cell wall, plasma membrane, nucleus, some free cytoplasmic membrane of unknown function, and numerous mitochondria. The mitochondria show clearly defined outer membranes and cristae, with definition comparable to that of the other cell membranes. Cells cultured at the medium aeration rate (Fig. 3) show a notable increase in the amount of the free cytoplasmic membrane and a decrease in the definition of the mitochondria, especially in the cristae which are very difficult to identify in some of the organelles. When examined in the electron microscope, the membranes of cells grown under conditions of low aeration are poorly defined from the surrounding cytoplasm.
This is especially true for the mitochondria (Fig. 4). Although mitochondrial profiles can still be identified, the outer membranes are very poorly defined and the cristae are almost unrecognizable. Conversely, there is a great increase in the free cytoplasmic membrane, which frequently has the appearance of parallel layers in close association with the nuclear membrane. The loss in membrane definition in cells grown under conditions of low aeration is evidently due in part to a lack of ergosterol and unsaturated fatty acids. Inclusion of these lipid components in the medium leads to some improvement in membrane definition to a degree comparable to that shown in Fig. 3.

The effects of growth in the presence of chloramphenicol or euflavine on the morphology of the mitochondria are quite distinct from the effects of oxygen restriction. Fig. 5 shows a section through a cell grown in the presence of $4 \mathrm{mg} / \mathrm{ml}$ chloramphenicol. The mitochondria are very elongated structures whose outer membranes appear normal, but whose cristae are of an abnormal, fragmented character, and in much smaller amount than normal. Occasionally, electron-opaque granules of unknown significance are seen among the residual cristae. The 


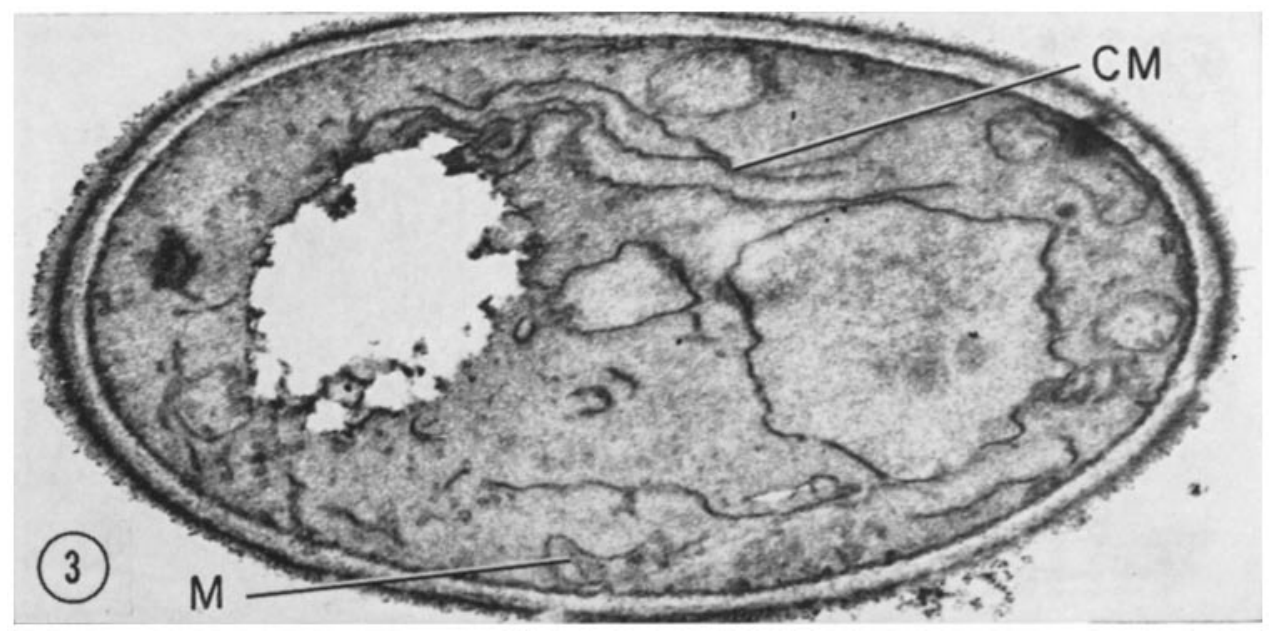

FigURE 3 Section through a representative cell of $C$. parapsilosis grown to the early stationary phase (16-18 hr) in the basic medium aerated at a rate of $250-300 \mathrm{ml}$ air $/ 30$ liters medium/minute. The mitochondria $(\boldsymbol{M})$ are notably smaller in size, poorer in definition and contain fewer cristae than the highly aerobic cells. At the same time an increase in the amount of cytoplasmic membrane $(C M)$ is observed. $\times$ 30,500 .

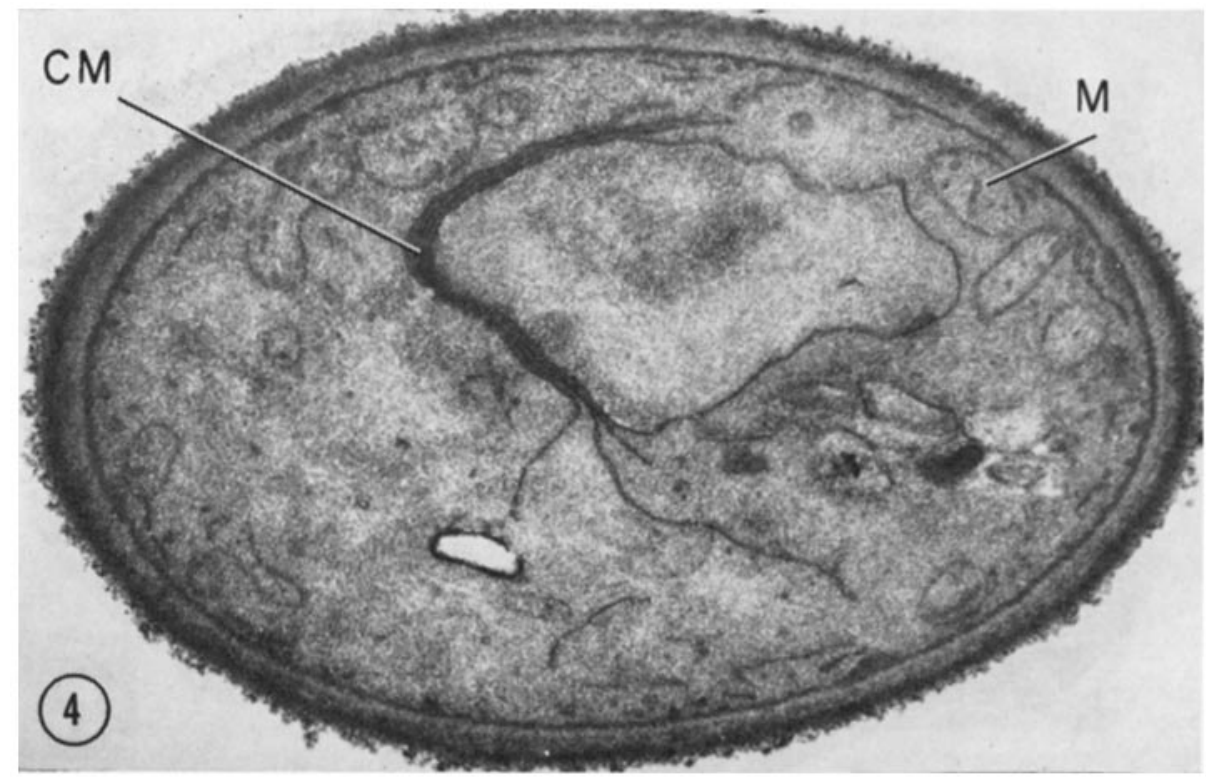

FIGURE 4 Section through a cell of $C$. parapsilosis grown for 16-18 $\mathrm{hr}$ in the basic medium aerated at the rate of $40-60 \mathrm{ml}$ air $/ 30$ liters medium/minute. The mitochondria $(M)$ are quite small and primitive and the mitochondrial membranes are poorly defined in comparison with the nuclear and cytoplasmic membrane systems. The cytoplasmic membrane $(C M)$ has increased both in amount and in degree of organization. In this micrograph, several strands are arranged contiguously with the nuclear membrane; similar structures are also frequently observed free in the cytoplasm. $\times 32,000$.

effect of chloramphenicol on the cytology is concentration dependent. Fig. 6 shows a cell grown in the presence of $2 \mathrm{mg} / \mathrm{ml}$ chloramphenicol. A similar appearance is seen in cells grown with $5 \mu \mathrm{g} / \mathrm{ml}$ euflavine. Fig. 7 illustrates the extreme type of cytology of cells cultured in the presence of $20 \mu \mathrm{g} / \mathrm{ml}$ euflavine; the changes are similar to those seen in Fig. 5, except for the 


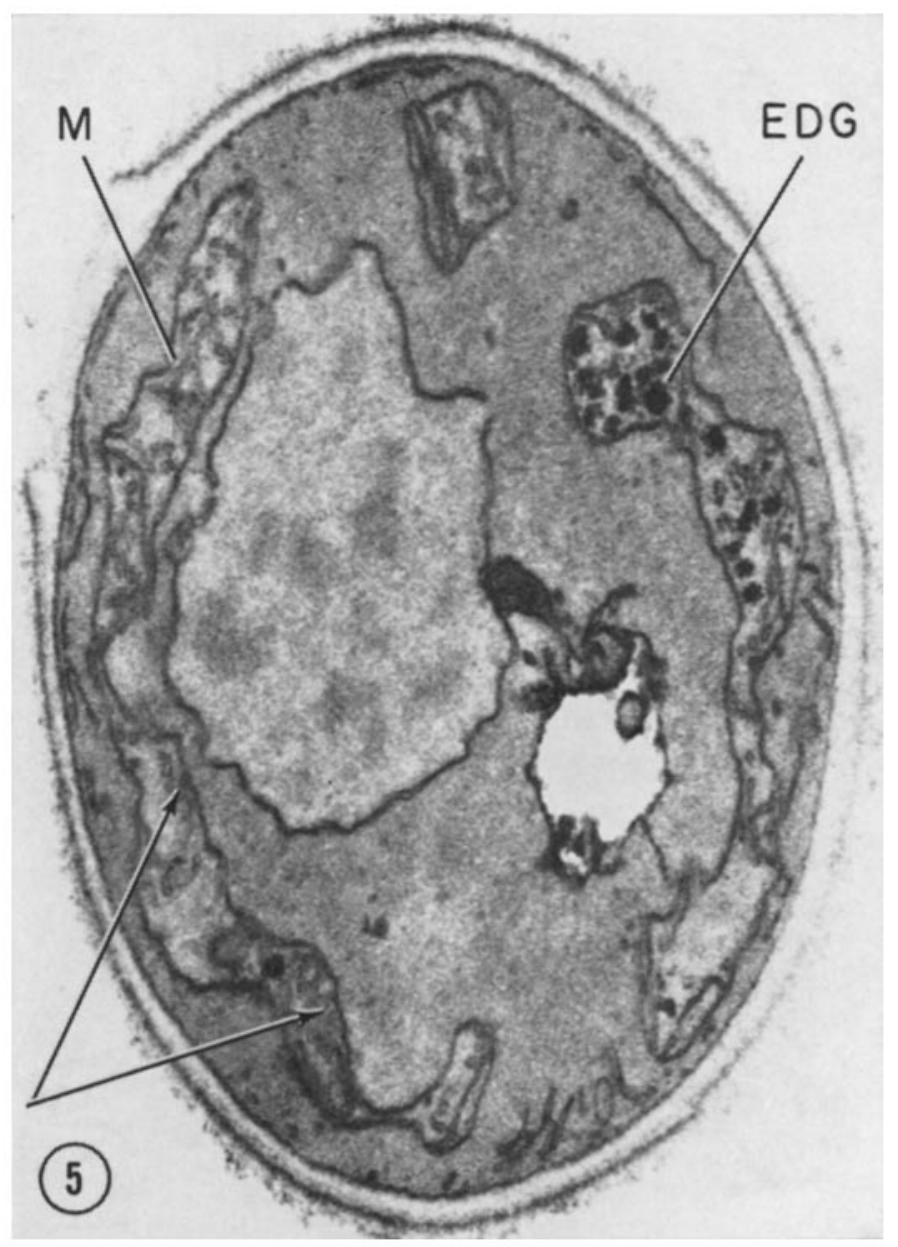

Figure 5 Section through a cell of C. parapsilosis grown for $16-18 \mathrm{hr}$ in medium containing $4 \mathrm{mg} / \mathrm{ml}$ of chloramphenicol. The main effect is on the mitochondria $(\boldsymbol{M})$ which are greatly elongated structures, containing considerably less cristae than seen in normal mitochondria. While some of the cristae appear well defined, in general they appear to be degenerate (arrows). One of the mitochondria contains a considerable amount of electron-dense granular material $(E D G)$ of unknown composition. $\times 37,000$.

absence of intramitochondrial granulations and the more markedly disorganized cristae. Fig. 8, a higher magnification of the region outlined in Fig. 7, shows a well-defined inner membrane contiguous with the outer one, suggesting that the inner membrane is intact. Micrographs of this kind can be commonly obtained; and coupled with the great reduction in the amount of cristae and essentially complete loss of cytochrome content of the organelles (see below), the data may be interpreted to suggest that the inner mitochondrial membrane may be an entity completely separate from the cristae. According to this interpretation, the mitochondrion would then consist functionally of a three-membrane system, comprising an outer membrane enclosing a bipartite inner membrane, the latter made up of the noncristal portion and the cristae (infolds). Alternatively, the loss of some components of the inner membrane system may result, in this instance, in a reorganization of its structure with preservation of the contours of the inner membrane contiguous with the outer membrane and with consequential preferential morphological alterations in the cristae.

\section{Cytochrome Content of Cells}

The cytochrome content of the whole cell homogenates was considerably influenced by the degree of aeration during growth (Table 1). The 
most marked effect was on the content of cytochromes $a$ and $a_{3}$, which in low aeration cells was $40 \%$ of that in high aeration cells. There was a smaller decrease in the cytochrome $c+c_{1}$, to about $70 \%$ of the high aeration level, while the cytochrome $b$ level appeared to be largely independent of the degree of aeration. The addition of ergosterol and unsaturated fatty acids to the growth medium had profound effects on the various cytochromes. Thus, at all levels of aeration, the cytochrome $a+a_{a}$ concentration was approximately twice that of the unsupplemented cells, so that the relative relationship between the cytochrome $a+a_{3}$ content and the degree of aeration observed in unsupplemented cells was preserved. The cytochrome $b$ content was about twice as high as in cells unsupplemented with lipid and remained largely independent of the oxygen supply. The cytochrome $c+c_{1}$ content of

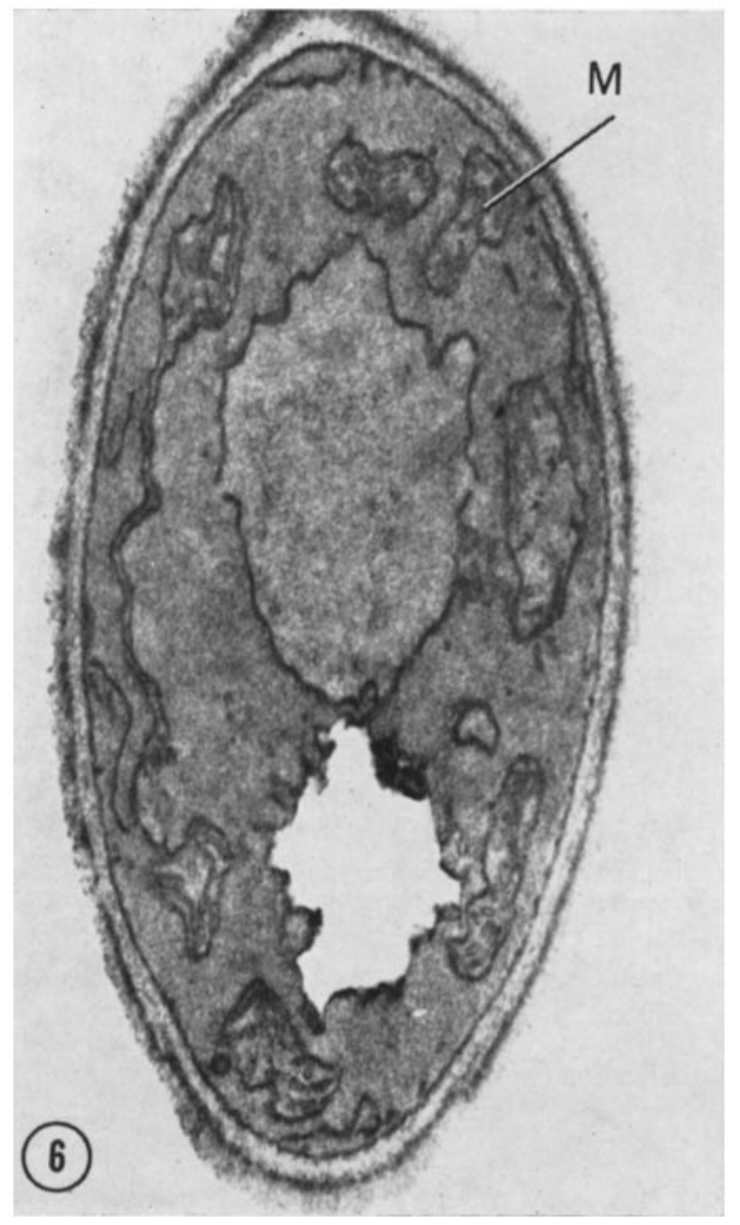

the cells grown with the lipid supplements was independent of the degree of oxygenation, in contrast to the results with the unsupplemented cells, and the actual content of these cytochromes was a little higher than that found in the most highly aerobic unsupplemented cells. The relative concentration ratios of the cytochromes thus varied within wide limits, depending on the supply of oxygen and lipids. These variations indicate that there is no obligate cytochrome stoichiometry in Candida mitochondria.

Growth of the cells in the presence of euflavine or chloramphenicol had profound effects on the cytochrome content of the cells (Table 1). The spectrum of whole cells grown in the presence of $20 \mu \mathrm{g} / \mathrm{ml}$ euflavine showed only a single absorption peak centered at $550 \mathrm{~m} \mu$ which could be accounted for essentially completely as cytochrome $c$.
Figure 6 Section through a cell of C. parapsilosis grown for $16-18 \mathrm{hr}$ in medium containing $2 \mathrm{mg} / \mathrm{ml}$ of chloramphenicol. The mitochondria (M) show changes less marked than those of Fig. 5. $\times 34,000$. 


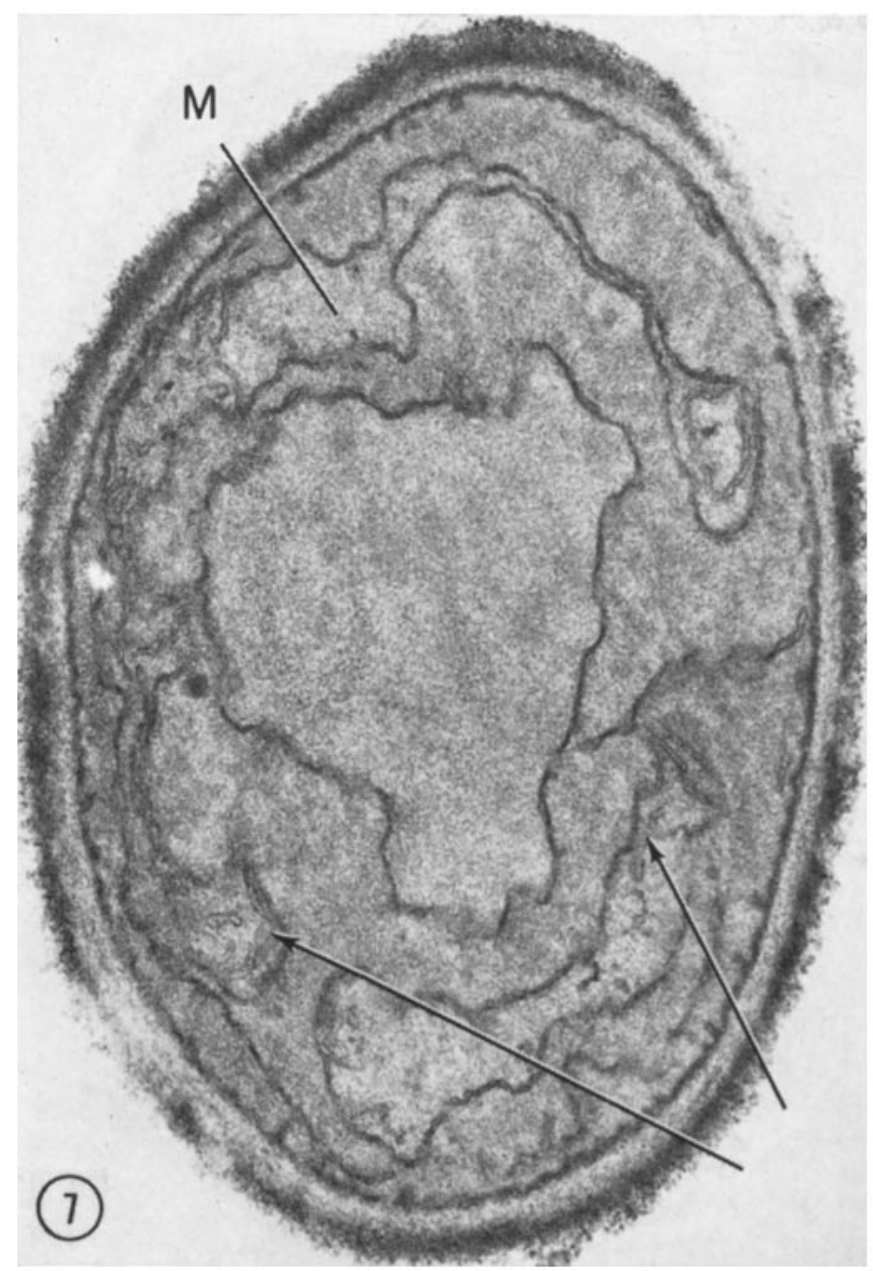

Figure 7 Section through a cell of C. parapsilosis grown for $16-18 \mathrm{hr}$ in medium containing $20 \mu \mathrm{g} / \mathrm{ml}$ of euflavine. As observed in chloramphenicol-treated cells, the mitochondria (M) contain a much reduced amount of cristae in comparison with normal mitochondria, and many of the cristae appear to be degenerate (arrows). $X$ 44,000 .
Examination of a whole particle fraction of such cells at room temperature and the temperature of liquid nitrogen after extraction of cytochrome $c$ failed to reveal the presence of cytochromes $a, a_{3}, b$, and $c_{1}$. Euflavine at concentration of $5 \mu \mathrm{g} / \mathrm{ml}$ strongly inhibited the formation of the four insoluble cytochromes; however, the inhibition was not complete.

At the maximum concentration of chloramphenicol attainable ( $4 \mathrm{mg} / \mathrm{ml}$ medium) the cytochrome $a, a_{3}$ content decreased to about $20 \%$ of the normal level, cytochrome $b$ decreased to about $40 \%$ of normal, and the combined cytochrome $c+c_{1}$ content of whole cells was increased by about $50 \%$ over the normal level. However, there was a considerable increase in the cytochrome $c$ content of the cells grown with chloramphenicol, so that (by difference) the cytochrome $c_{1}$ content decreased approximately in parallel with the cytochrome $b$ content. Chloramphenicol is thus much less effective than euflavine as an inhibitor of cytochrome synthesis in this organism.

\section{Respiratory Activity of Whole Cells}

We have found that there are two respiratory systems in $C$. parapsilosis: one cyanide insensitive and as yet uncharacterized, and the other the cyanide-sensitive mitochondrial cytochrome system. The cyanide-insensitive system is of major quantitative significance and, in high aeration control cells, it can account for about $50 \%$ of the total respiratory activity of the cells (Table II). Cells grown in euflavine $(20 \mu \mathrm{g} / \mathrm{ml})$ have no cyanide-sensitive respiration but they retain the cyanide-insensitive system and its activity is similar to that of the high aeration control cells. 


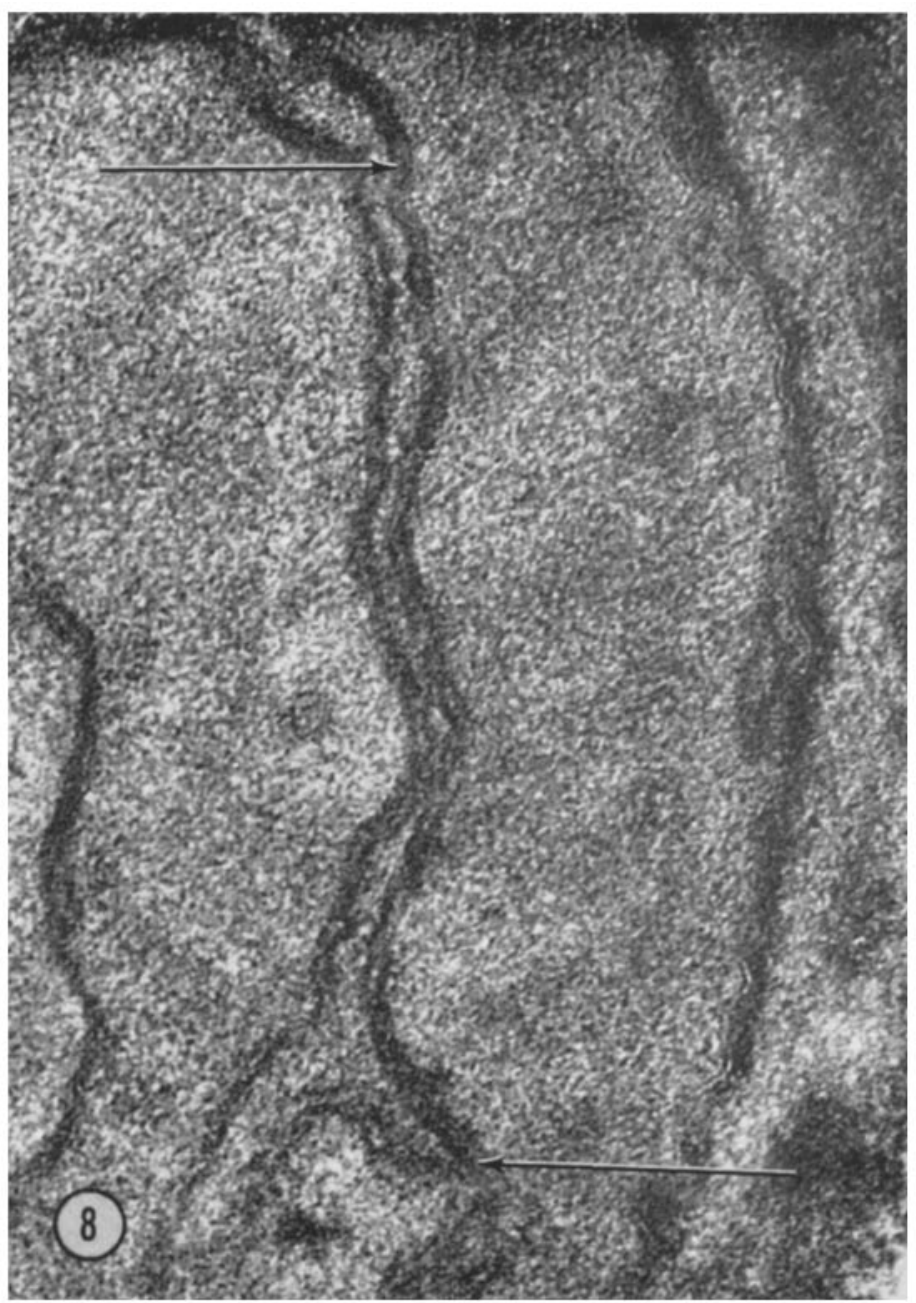

Figure 8 Enlargement of portion of the cell depicted in Fig. 7 showing clearly the "double membrane" nature of the limiting mitochondrial membrane (arrows). Thus the inner layer of the external membrane, although topographically continuous with the cristae, is apparently little affected by growth in the presence of euflavine, suggesting that these membranes may in fact belong to separate systems. $\times 128,000$.

Consistent with the incomplete inhibition of particulate cytochrome synthesis by chloramphenicol $(4 \mathrm{mg} / \mathrm{ml})$, a considerable proportion of the respiration is still cyanide-sensitive. To some extent, conditions of medium and low aeration affect both the cyanide-sensitive and -insensitive systems, reducing their activities (Table II). This effect contrasts with that of the druss already described. The cyanide-insensitive system occurs in the $105,000 \mathrm{~g}$ supernatant of cells disrupted in the French pressure cell.

\section{Other Mitochondrial Enzymes}

To assess the specificity of the actions of the drugs and of oxygen restriction on the mitochondria, assays were performed on succinate dehydrogenase, a representative mitochondrial membrane-bound enzyme, and on fumarase and malate dehydrogenase, representative of readily solubilized mitochondrial enzymes. No attempt was made to identify possible mitochondrial and cytoplasmic isoenzymes, and thus assay them separately. As may be expected from 
TABLE I

Cytochrome Content of Cells of C. Parapsilosis Grown Under Various Conditions

\begin{tabular}{|c|c|c|c|c|}
\hline \multirow[b]{3}{*}{ Growth conditions } & \multicolumn{4}{|c|}{ Cytochrome } \\
\hline & $a+a_{3}$ & $b$ & $c+c_{1}$ & $c$ \\
\hline & \multicolumn{4}{|c|}{$\mathrm{m} \mu \mathrm{moles} / 100 \mathrm{mg}$ whole cellular protein } \\
\hline High aeration & 7.0 & 13 & 20 & 11 \\
\hline Medium aeration & 3.3 & 15 & 18 & - \\
\hline Low aeration & 2.7 & 14 & 14 & - \\
\hline High aeration + lipid & 14 & 28 & 23 & - \\
\hline Medium aeration + lipid & 5.7 & 29 & 24 & - \\
\hline Low aeration + lipid & 4.7 & 30 & 25 & - \\
\hline Chloramphenicol $2 \mathrm{mg} / \mathrm{ml}$ & 4.3 & 9.3 & 32 & 18 \\
\hline Chloramphenicol $4 \mathrm{mg} / \mathrm{ml}$ & 1.3 & 5.2 & 30 & 27 \\
\hline Euflavine $5 \mu \mathrm{g} / \mathrm{ml}$ & 0.7 & trace & 25 & 20 \\
\hline Euflavine $20 \mu \mathrm{g} / \mathrm{ml}$ & undetected & trace & 24 & 22 \\
\hline
\end{tabular}

The results shown represent the mean of three separate experiments. Cells were grown for 16-18 hours, and quantitatively disrupted in the French Pressure Cell (cf. Methods). The cytochrome content of the resultant cell-free whole homogenate was determined by the technique of difference spectroscopy, using the extinction coefficients for mammalian cytochromes (Estabrook and Holowinsky, 1961). Euflavinetreated cells contain traces of a $b$-type cytochrome, but it is very difficult to determine the amounts from the difference spectra, owing to the presence of a large excess of cytochrome $c$ in these cells. Cytochrome $c$ content of whole cells was determined as described by Sels et al. (1965).

previous work with $S$, cerevisiae (footnote 5; ClarkWalker and Linnane, 1967), the activities of all three enzymes decreased in cells subjected to any of these treatments, but even with $20 \mu \mathrm{g} / \mathrm{ml}$ euflavine there was still considerable residual activity of each enzyme (Table III). Succinate dehydrogenase always showed the greatest relative decrease in activity. While low aeration cells preserved considerable insoluble cytochrome content, as against the complete loss in the cells grown in $20 \mu \mathrm{g} / \mathrm{ml}$ euflavine, both types of cell had comparable concentrations of fumarase and of the dehydrogenases. Again, the effect of chloramphenicol was less marked than that of euflavine.

\section{Glucose Repression}

Saccharomyces cerevisiae is well known to be very sensitive to the concentration of glucose in its growth medium, with respect to number and morphology of mitochondria, cytochrome and other enzyme content, and lipid composition

5 M. J. Vary, C. L. Edwards, and P. R. Stewart. 1969. Arch. Biochem. Biophys. 130:235
(Ephrussi et al., 1956; Mahler et al., 1968; Polakis et al., 1964; Linnane, 1965; Lukins et al., 1966; and footnote 6). Under high aeration conditions concentrations of glucose between $0.7 \%$ and $20 \%$ in the growth medium were investigated with the present organism and practically no differences were found either in whole cell absorption spectra (used as an index of cytochrome content) or in electron microscope appearances. Even with $20 \%$ glucose in the medium, mitochondria were numerous and had well-defined profiles and cristae indistinguishable from those in the cell shown in Fig. 2.

\section{Reversibility of Drug Effects}

The enzymatic and morphological characteristics described proved to be stable in cells grown on media containing chloramphenicol or euflavine for over 20 generations, provided the drugs were continually present. When cells were transferred to normal drug-free medium, the growth rate

${ }^{6}$ H. B. Lukins, D. Jollow, P. G. Wallace, and A. W. Linnane. 1968. Aust. J. Exp. Biol. Med. Sci. 46:651 
Table II

The Respiratory Activity of Whole Cells of $C$. Parapsilosis Grown Under Various Conditions

\begin{tabular}{|c|c|c|}
\hline \multirow{3}{*}{ Growth conditions } & \multicolumn{2}{|c|}{$\begin{array}{l}\text { Respiratory activity } \\
\text { m } \mu \text { g atoms oxygen }\end{array}$} \\
\hline & \multicolumn{2}{|c|}{ utilized/mg dry wt } \\
\hline & \multicolumn{2}{|c|}{ cells/minute } \\
\hline & No inhibitor & $\begin{array}{c}+0.5 \mathrm{mM} \\
\mathrm{KCN}\end{array}$ \\
\hline High aeration & 120 & 55 \\
\hline Medium aeration & 84 & 48 \\
\hline Low aeration & 72 & 37 \\
\hline Chloramphenicol $4 \mathrm{mg} / \mathrm{ml}$ & 96 & 65 \\
\hline Euflavine $20 \mu \mathrm{g} / \mathrm{ml}$ & 65 & 67 \\
\hline
\end{tabular}

The values cited are the means of three determinations, with glucose as substrate.

\section{TABLE III}

The Levels of Some Citric Acid Cycle Enzymes in C. Parapsilosis Grown Under Different Conditions

\begin{tabular}{lrcc}
\hline & \multicolumn{3}{c}{ Enzyme } \\
\cline { 2 - 4 } & $\begin{array}{c}\text { Succinate } \\
\text { dehydro- } \\
\text { genase }\end{array}$ & $\begin{array}{c}\text { Malate } \\
\text { dehydro- } \\
\text { genase }\end{array}$ & Fumarase \\
\cline { 2 - 4 } & $\begin{array}{c}\text { Mmoles substrate transformed/ } \\
100 \mathrm{mg} \text { protein/min }\end{array}$ \\
\hline High aeration & 32 & 410 & 90 \\
Medium aeration & 8 & 290 & 43 \\
Low aeration & 6 & 270 & 30 \\
Euflavine $5 \mu \mathrm{g} / \mathrm{ml}$ & 4 & 250 & 43 \\
Euflavine $20 \mu \mathrm{g} / \mathrm{ml}$ & 4 & 200 & 38 \\
Chloramphenicol $2 \mathrm{mg} /$ & 14 & 390 & 70 \\
$\quad$ ml & & & \\
Chloramphenicol $4 \mathrm{mg} /$ & 9 & 310 & 63 \\
$\quad$ ml & & & \\
\hline
\end{tabular}

The results shown represent the mean of three separate experiments. The enzymic activities of the cell-free whole homogenates were determined as described in Methods.

returned to the normal uninhibited rate and the morphology and cytochrome spectrum returned to normal. That no actual genetic information was lost by cells cultured in the presence of chloramphenicol or euflavine was shown by the fact that all such cells were capable of forming colonies on plating onto drug-free solid medium and that the spectrum of a number of cultures derived from these individual colonies had re- turned to normal. There was thus no evidence that either euflavine, which produces the permanent "petite" mutation in Saccharomyces species at high frequency, or chloramphenicol, which does not induce the petite mutation in Saccharomyces, acts as a mutagen on Candida. All changes observed were purely at the phenotypic level, and reversion to normal occurred in each cell as soon as the drug was withdrawn.

It may be added that the antibiotics erythromycin and lincomycin have overall effects on Candida very similar to those of chloramphenicol. Also, ethidium bromide, recently reported to induce the petite mutation in $S$. cerevisiae to the extent of $100 \%$ (Slonimski et al., 1968), does not induce the petite mutation in $C$. parapsilosis but, like euflavine, reversibly inhibits the synthesis of the four mitochondrial cytochromes $a, a_{3}, b$, and $c_{1}$.

\section{Mitochondrial Amino Acid Incorporation}

The effect of chloramphenicol, erythromycin, lincomycin, euflavine, and ethidium bromide on

\begin{tabular}{|c|c|c|}
\hline \multirow[t]{2}{*}{ Drug } & Concentration & $\begin{array}{c}\text { Inhibition of } \\
\text { mitochondrial } \\
\text { protein } \\
\text { synthesis }\end{array}$ \\
\hline & $m M$ & $\%$ \\
\hline \multirow[t]{3}{*}{ Chloramphenicol } & 0.06 & 75 \\
\hline & 0.6 & 90 \\
\hline & 6 & 100 \\
\hline \multirow[t]{3}{*}{ Lincomycin } & 0.1 & 75 \\
\hline & 0.4 & 80 \\
\hline & 10 & 100 \\
\hline \multirow[t]{3}{*}{ Erythromycin } & 0.07 & 60 \\
\hline & 0.3 & 60 \\
\hline & 1.5 & 50 \\
\hline \multirow[t]{3}{*}{ Euflavine } & 0.003 & 18 \\
\hline & 0.02 & 70 \\
\hline & 0.06 & 100 \\
\hline \multirow[t]{3}{*}{ Ethidium bromide } & 0.003 & 40 \\
\hline & 0.02 & 80 \\
\hline & 0.06 & 100 \\
\hline
\end{tabular}

The incorporation of ${ }^{14} \mathrm{C}$-leucine in the control tubes was $17 \mu \mu$ moles/mg mitochondrial protein/ $20 \mathrm{~min}$, and was completely dependent on the addi tion of an ATP-generating system. 
amino acid incorporation into protein by isolated mitochondria is shown in Table IV. All five compounds inhibit the incorporation.

\section{DISCUSSION}

\section{Effect of Aeration}

It is apparent that the mitochondrial composition in Candida parapsilosis is greatly affected by the oxygen tension of the growth medium. Low oxygen tension during growth leads to a diminution in the number of mitochondria; their outer membranes become less distinct than normal, in comparison with the other membranes of the cell, and there is almost complete disappearance of cristae. These morphological changes are accompanied by marked decreases in the content of cytochrome oxidase and succinate dehydrogenase and moderate decreases in cytochromes $c+c_{1}$ and the two soluble Krebs' cycle enzymes studied. There is also a very marked slowing of growth and decrease in cell yield under conditions of low oxygenation. The organism is unable to grow under completely anaerobic conditions, even in media supplemented with yeast extract, unsaturated fatty acids, and ergosterol; this may represent the inability of its glycolytic system to provide adequate energy, or the lack of some as yet uncharacterized nutrient whose synthesis requires oxygen. It is, however, possible to achieve marked increases in the morphological definition of the mitochondrial cristae, with concomitant increases in cytochrome content, by supplementation of the growth medium with ergosterol and unsaturated fatty acids, the synthesis of which requires molecular oxygen. Even with these additions there is still no significant effect on growth rates or cell yields, which remain primarily dependent on the degree of oxygenation of the medium.

The effects of oxygen limitation thus represent a multivalent phenomenon not restricted only to effects on mitochondria and their enzymes and associated lipids. Moreover, the composition of Candida mitochondria is quite variable under different growth conditions, and there is no specific stoichiometry preserved between any of the enzymes assayed; there is not even a parallel decrease in the content of the insoluble cytochromes $a_{3} a_{3}, b$, and $c_{1}$. However, there are always recognizable mitochondrial profiles in the cells, no matter what the conditions of growth. These changes are in marked contrast to the extent of change which may be observed following anaerobic growth of $S$. cerevisiae; anaerobically, this organism grows well, is subject to catabolite repression, no longer synthesizes any of the five cytochromes $a, a_{3}, b, c_{1}$, and $c$, and may contain no readily recognizable mitochondrial profiles (Wallace et al., 1968). A further, very significant difference between the two organisms is the presence in Candida of a cyanide-insensitive respiratory system, in addition to the mitochondrial cytochrome oxidase pathway. The cyanideinsensitive system is capable of carrying out a significant portion of total respiratory activity of the cell, irrespective of the degree of aeration of the growth medium.

\section{Effect of Drugs}

In confirmation of the earlier results of Bulder (1964) and De Deken (1966), we have found that euflavine does not induce the petite mutation in Candida, nor does ethidium, as described herein. However, both drugs clearly inhibit the mitochondrial protein-synthesizing system in $C$. parapsilosis, and the resultant cell then resembles a phenocopy of the petite mutant of $S$. cerevisiae. Taken together with the information that these two drugs react with DNA by intercalating between adjacent base pairs (Lerman, 1964; Crawford and Waring, 1967), the results suggest that the organization of $C$. parapsilosis mitochondrial DNA is likely to be different from that of $S$. cerevisiae mitochondrial DNA. The observation that both ethidium and euflavine can completely inhibit amino acid incorporation by isolated mitochondria at a concentration as low as 0.06 mM suggests that these two compounds may also react at sites other than mitochondrial DNA, or else that all in vitro mitochondrial amino acid incorporation into protein is directly and completely linked to transcription. This latter situation is unlikely, in view of the incompleteness of the inhibition by actinomycin $\mathrm{D}$ of in vitro protein synthesis in mammalian mitochondria (Kroon, 1965; Mahler et al., 1968, Wheeldon and Lehninger, 1966.)

All three antibiotics chloramphenicol, lincomycin, and erythromycin strongly inhibit in vivo particulate mitochondrial cytochrome synthesis, albeit not completely like euflavine and ethidium. However, as shown herein, chloramphenicol does produce great changes in mitochondrial mor- 
phology, comparable to those induced by euflavine. All three antibiotics inhibit mitochondrial protein synthesis in vitro, and at high concentrations both chloramphenicol and lincomycin are capable of completely inhibiting the system. The incomplete nature of the in vivo inhibition by these two antibiotics may therefore be due to permeability factors, such as have been found in $S$. cerevisiae (Linnane, Lamb et al., 1968). Recent experiments in our laboratory ${ }^{3}$ have shown that while chloramphenicol inhibits mitochondrial protein synthesis in a wide variety of animal cells, erythromycin and lincomycin have no effect on amino acid incorporation into protein by mitochondria isolated from the livers of a variety of mammals. It is clear that several evolutionary changes have occurred in the nature of the autonomous elements of mitochondria. Thus, the facultative anacrobe $S$. cerevisiae and the obligate aerobe $C$. parapsilosis differ in their response to the cytoplasmic mutagens euflavine and ethidium but respond similarly to the three antibiotics discussed above. Mammalian liver mitochondria are, in addition, no longer sensitive to the two antibiotics lincomycin and erythromycin. An accumulating body of evidence indicates that all three antibiotics react with the $50 \mathrm{~S}$ subunit of the ribosome (Vazquez 1966; Krembel and Apirion, 1968; Chang and Weisblum, 1967; Linnane, Saunders et al., 1968; Lamb et al., 1968), so that phylogenetic changes have evidently occurred at the level of the mitochondrial ribosome. It may also be added that Marchant and Smith (1968) have reported that, unlike the situation in $S$. cerevisiae and $C$. parapsilosis, cells of Pythium ultimum grown in the presence of chloramphenicol do not show extensive morphological changes in mitochondria but appear to have lost the knobs and stalks associated with the mitochondrial cristae.

\section{REFERENCES}

Biggs, D. R. and A. W. Linnane. 1963. Biochim. Biophys. Acta 78:785.

Bulder, C. J. E. A. 1964. Antonie van Leeuwenhoek J. Microbiol. Serol. 30:442.

Chang, F. N. and B. Weisblum. 1967. Biochemistry. 6:836.

Glark-Walker, G. D. and A. W. Linnane. 1966. Biochem. Biophys. Res. Commun. 25:8.

Glark-Walker, G. D. and A. W. Linnane. 1967. J. Cell Biol. 34:1.
The complete loss of the insoluble cytochromes in cells grown in $20 \mu \mathrm{g} / \mathrm{ml}$ euflavine, coupled with the complete inhibition of mitochondrial protein synthesis in vitro by this concentration of the drug, is consistent with a complete inhibition of mitochondrial protein synthesis in vivo. Thus, the residual mitochondrial components in such cells are presumably products of the cytoplasmic protein-synthesizing system, a position similar to the one already described at length in $S$. cerevisiae (Clark-Walker and Linnane, 1967; Linnane, 1968; Linnane, Biggs et al., 1968). In this regard there is clear electron micrographic evidence that, in addition to the outer mitochondrial membrane, the inner membrane is also preserved in such cells; all changes seem to be confined to the cristae, which do not, however, entirely disappear. Study of the effects of inhibition of mitochondrial protein synthesis in Saccharomyces requires growth on medium containing a fermentable sugar, and so is inextricably interwoven with the effects of catabolite repression occurring simultaneously. Perhaps it is the lack of this glucose repression in Candida which permits the study of the contribution of the mitochondrial protein-synthesizing system as a single entity. Our interpretation of these structural findings, then, is that the outer and inner membranes are separate structures, whose components are synthesized by the cytoplasmic ribosomes, and that the cristae represent a third membrane component, manufactured partly by the cytoplasm and partly by the mitochondrion. This apparently separate origin of inner membrane and cristae would agree with the functional differences in them as suggested by Penniston et al. (1968)

This investigation was supported by U. S. Public Health Service Grant GM10496-06.

Received for publication 31 December 1968.

Crawford, L. V. and M. J. Waring. 1967. J. Mol. Biol. 25:23.

DE Deken, R. H. 1966. J. Gen. Microbiol. 44:157.

EPHRUSSI, B. 1953. Nucleo-cytoplasmic relations in micro-organisms. Clarendon, Oxford.

Ephrussi, B., P. P. Slonimski, Y. Yotsuyanagi, and J. Tavlitzki. 1956. Compt. Rend. Trav. Lab. Ser. Physiol. Carlsberg. 26:87.

Estahrook, R. W. and A. Holowinsky. 1961. $J$. Biophys. Biochem. Cytol. 9:248. 
Firkin, F. G. and A. W. Linnane. 1968. Biochem. Biophys. Res. Commun. 32:398.

Jollow, D., G. M. Kelilerman, and A. W. Linnane. 1968. J. Cell Biol. $37: 221$.

Krembel, J. and D. Apirion. 1968. J. Mol. Biol. 33: 363.

Kroon, A. M. 1965. Biochim. Biophys. Acta. 108:275.

Lamb, A. J., G. D. Clark-Walker, and A. W. Linnane. 1968. Biochim. Biophys. Acta. 161:415.

Lerman, L. S. 1964. J. Mol. Biol. 10:367.

Linnane, A. W. 1965. In Oxidases and related redox systems. T. E. King, H. S. Mason, and M. Morrison, editors. John Wiley \& Sons Inc., New York. 2:1102.

Linnane, A. W. 1968. In Biochemical aspects of the biogenesis of mitochondria. E. C. Slater, J. M. Tager, S. Papa, and E. Quagliariello, editors. Adriatica Editrice, Bari, Italy. 333.

Linnane, A. W., D. R. Biggs, M. Huang, and G. D. Glark-Walker. 1968. In Aspects of yeast metabolism. R. K. Mills, editor. Blackwell Scientific Publications Ltd., Oxford. 217.

Linnane, A. W., A. J. Lamb, C. Ghristodoulou, and H. B. Lukins. 1968. Proc. Natl. Acad. Sci. U. S. 59:1288.

Linnane, A. W., G. Saunders, E. Gingold, and H. B. Lukins. 1968. Proc. Natl. Acad. Sci. U.S.A. 59:903.
Lodder, J. and N. J. W. Kreger-VAN RIJ. 1967. The yeasts. North-Holland Publishing Company, Amsterdam.

Mahler, H. R., K. K. Tewari, and J. Jayaraman. 1968. In Aspects of yeast metabolism. R. K. Mills, editor. Blackwell Scientific Publications Ltd., Oxford. 247.

Marchant, R. and D. G. Smith. 1968, J. Gen. Microbiol. 50:391.

Penniston, J. T., R. A. Harris, J. Asai, and D. E. Green. 1968. Proc. Natl. Acad. Sci. U.S.A. 59:624.

Polakis, E. S., W. Bartley, and G. A. Meek. 1964. Biochem. J. 90:369.

Robbie, W. A. 1948. Methods Med. Res. 1:307.

Sels, A. A., H. Fukuhara, G. Pere, and P. P. Slonimski. 1965. Biochim. Biophys. Acta. 95:486.

Shapiro, L., L. I. Grossman, J. Marmur, and A. K. KLEINSChMidt. 1968. J. Mol. Biol. 33:907.

Slonimski, P. P., G. Perrodin, and J. H. Croft. 1968. Biochem. Biophys. Res. Commun. 30:232.

VazQuez, D. 1966. Symp. Soc. Gen. Microbiol. 16: 169.

Waliace, P. G., M. Huang, and A. W. Linnane. 1968. J. Cell Biol. 37:207.

Wheeldon, L. W. and A. L. Lehninger. 1966. Biochemistry. 5:3533. 